\title{
Diagnostic Assessment in Learning Optics based on Inquiry Laboratory
}

\author{
R. Qadar ${ }^{1}$, Z. Haryanto ${ }^{2}$, Samsiah ${ }^{3}$ \\ ${ }^{1,2}$ Faculty of Teacher Training and Education, Mulawarman University, Samarinda, East Kalimantan, Indonesia \\ SMPN 27 Samarinda, East Kalimantan, Indonesia \\ riskanqadar@fkip.unmul.ac.id, zeni.haryanto@fkip.unmul.ac.id
}

\begin{abstract}
This study aims to determine the improvement and differences of learners' learning outcomes based on diagnostic assessment on learning optics based on inquiry lab. The research used experimental design on students of grade VIII SMPN 27 Samarinda as research subjects. Quantitative data were collected using a limited response instrument with multiple choice model. The instruments used are arranged based on the dimensions of knowledge that include conceptual and procedural, while the cognitive process includes remembering, understanding, applying, and analyzing. The inquiry laboratory approaches used include: observation, manipulation, generalization, verification, and application. The results showed an increase in student learning outcomes. Learning optics based on Inquiry laboratory shows differences in learning outcomes.
\end{abstract}

Keywords--diagnostic assessment, inquiry laboratory, optical learning.

\section{INTRODUCTION}

Assessment is one of the teacher activities that becomes the task and the important role to know the learning progress of learners [1, 2]. Assessments that can be done in learning are divided into three competencies, namely the aspects of cognitive/knowledge, affective aspects, and psychomotor aspects. The three aspects complement each other. Cognitive aspect is a competency that focuses on the ability to master the concept of learners. The affective aspect is a competency that focuses on emotional things, values, interests, concerns, motivations, and attitudes. Furthermore, the psychomotor aspect is a competency that focuses on the skills performed [3, $4,5,6,8,9]$.

Many teachers measure learners' learning outcomes after learning has been done. However, there are rarely teachers who want to know the ability of the learner's early knowledge and skills and the necessary needs to help achieve the learning objectives. In order to realize the initial and necessary knowledge and skills needed in the lesson, a diagnostic assessment is necessary [10]. Diagnostic assessments may also be used to determine improvements in learning outcomes after treatment.

The students of grade VIII SMPN 27 Samarinda were the subject of diagnostic assessment research before the learning optics based on inquiry lab was conducted. Understanding the concepts of optics through an inquiry laboratory approach is taught with the syntax centered on the learner. The learning phase of the inquiry laboratory approach consists of five stages: observation, manipulation, generalization, verification, and application $[11,12,13]$.

This research was conducted to determine the difference and increase learning outcomes between the initial tests and the final test after using the inquiry laboratory approach. The problem to be investigated is the diagnostic assessment of learning optics based on laboratory inquiry.

\section{METHOD}

\section{A. Subject}

The optical lesson in this research was attend by thirty students of grade VIII SMP Negeri 27 Samarinda as subject in optical learning of mirror and lens material through inquiry laboratory approach. All subjects have no experience in physics science teaching using inquiry approach. At the learning stage using this inquiry laboratory approach, learners are required to learn in advance the process of formation of shadows on mirrors and lenses.

\section{B. Inquiry Laboratory Approach}

The use of inquiry learning approaches in learning focuses on how learners learn. The understanding of the concept of shadow formation in mirrors and lenses in the inquiry laboratory approach consists of five sequential stages: observation, manipulation, generalization, verification, and application. Observation is the first stage, activities undertaken to encourage curiosity and generate responses from learners. The second stage of manipulation, done to get data from different variables. The third stage of generalization, done to get the conclusion based on the results of observation on manipulation activities. The fourth stage of verification, conducted to match data obtained under the laws / theories / principles of the literature. The fifth stage of application, used to solve problems that correspond to the laws / theory / principles that have been obtained. The learning characteristics of the inquiry laboratory approach the question posed to learners or learners to the teacher.

Implementation of learning with inquiry lab approach is done in the laboratory. All learners do practicum activities to find images of objects from mirrors and lenses. Number of 
learning meetings conducted four times. The first study looks for shadows of objects formed from a concave mirror, a second learning for convex mirrors, a third learning for convex lenses, and a fourth learning for concave lenses.

\section{Data Collecting}

There are two data collected in this research, namely diagnostic test data (preliminary test) and final test data. Form of the initial test instrument and the final test is a multiplechoice model consisting of 30 question items. Both instruments have the same cognitive aspect content. Initial tests are performed before the learner receives the learning and the final test is performed after the mirror and lens learning has been completed.

The content of the cognitive aspect instrument uses Bloom's revised taxonomy domain that consists of the dimensions of knowledge and cognitive processes. The dimensions of knowledge used consist of conceptual and procedural. The cognitive processes used are: remembering (C1), understanding (C2), applying (C3), and analyzing (C4) [5]. Based on the dimensions of knowledge and cognitive processes used, the number of conceptual $\mathrm{C} 1$ as much as two questions, conceptual $\mathrm{C} 2$ as much as 19 questions, procedural $\mathrm{C} 3$ as much as 4 questions, and procedural $\mathrm{C} 4$ as much as 5 questions.

\section{Data Analysis}

The data collected in the form of preliminary and final test results will be tested statistically and analyzed qualitatively and quantitatively. Statistical test conducted in the form of descriptive test, $\mathrm{t}$ test, and $\mathrm{N}$-gain test.

\section{RESULTS AND DISCUSSION}

The results of the diagnostic assessment are preliminary and final tests are presented in categories; minimum score, maximum score, average score, average score of $\mathrm{N}$-gain, homogeneity test, normality test, and t test as shown in Table I and Table II.

TABLE I. RESULTS OF DATA ANALYSIS

\begin{tabular}{|l|l|l|l|l|}
\hline \multirow{2}{*}{$\begin{array}{l}\text { Type of } \\
\text { Test }\end{array}$} & \multicolumn{3}{|l|}{ Score } & Mean \\
\cline { 2 - 4 } & Minimum & Maximum & Score & N-gain \\
\hline Initial & 9 & 48 & 25 & \multirow{2}{*}{0,35} \\
\hline Final & 30 & 78 & 51 & \\
\hline
\end{tabular}

TABLE II. RESULTS OF HOMOGENITY, NORMALITY AND T TEST

\begin{tabular}{|l|l|l|l|}
\hline \multirow{2}{*}{$\begin{array}{l}\text { Type of } \\
\text { Test }\end{array}$} & Test & \multirow{2}{*}{$\begin{array}{c}\text { T Test } \\
\text { Sig (2-tailed) }\end{array}$} \\
\cline { 2 - 3 } & Homogenity & $\begin{array}{l}\text { Normality } \\
\text { Kurtosis }\end{array}$ & 0,000 \\
\hline Initial & - & - & 0,293 \\
\hline Final & 0112 & 0,29 & \\
\hline
\end{tabular}

Prior to the learning of optical based on laboratorim inquiry on the learner, first diagnostic assessment was done. The results obtained show early ability to mirror and lens concept is still categorized very low. This is seen with a minimum score of 9 , a maximum score of 48 , and an average score of 25 . In general, learners have not understood both the real and virtual image, the shadow-forming rays, and the shading of the shadows formed. However, some learners have understood the types of mirrors and lenses, the size of the shadows displayed and the distance of objects and shadows contained in the picture. Items that question the distance of objects, the distance of the shadow, or the shadow without the image, are generally not well understood.

Based on the ability to understand the concepts and skills of the early learners, it is designed learning activities that can improve understanding of concepts and skills. Inquiry-based optical learning is conducted four times. Each meeting strives to understand the ability of the concept and skills of students is increasing. Qualitative and quantitative data on the progress of learners in the form of assessment is always done during the learning takes place.

Optical learning at the first meeting discusses and practices the formation of shadows in concave mirrors. The first stage of observation, the teacher asked the question "How the process of shadow forming objects from a concave mirror? Does the distance of the object affect the distance of the shadow? "Next the learner experiments on the activity sheet and observes by observing the distance of the object and the distance of the shadow to the mirror. The second stage of manipulation, the teacher asks the question "What is the focal distance of the concave mirror?" Next learners manipulate the independent variables with the distance of different objects and get the distance of different shadows also to the mirror. The third stage of generalization, the teacher had to calculate the focus distance of the concave mirror. Further learners do calculations to find the focus distance based on the distance data objects and the distance of the shadow that collected. The fourth stage of verification, the teacher asked to make a conclusion. Furthermore, learners make conclusions and match the results of calculations with the concave focus of the actual concave mirror. The fifth stage of application, the teacher gives a number of problems to apply the calculation based on the data made. Further learners calculate the distance and shadow properties based on the data provided. When the implementation of learning takes place the teacher conducts assessment to know the achievement of learners towards the understanding of the concepts and skills undertaken. Learners who have not understood concepts and skills will be described further. In general, learners do not experience significant difficulties when learning takes place.

Optical learning at the second meeting discusses and practices shadow formation in convex mirrors. In the first stage of observation, the teacher asks the question "How is the process of shaping objects from convex mirror? Does the distance of the object affect the distance of the shadow? "Next the learner experiments on the activity sheet and observes by observing the distance of the object and the distance of the shadow to the mirror. At this stage determine the distance of the object shadow using the help of a flat mirror. The second stage of manipulation, the teacher asks the question "What is the focal distance of the convex mirror?" Then, the learners manipulate the independent variables with the distance of different objects and get the distance of different shadows also to the mirror. The third stage of generalization, the teacher has 
to calculate the focus distance of convex mirror. Further learners do calculations to find the focus distance based on the distance data objects and the distance of the shadow that collected. The fourth stage of verification, the teacher asked to make a conclusion. Furthermore, learners make conclusions and match the results of calculations with the focus distance of the actual convex mirror. The fifth stage of application, the teacher gives a number of problems to apply the calculation based on the data made. Further learners calculate the distance and shadow properties based on the data provided. When the implementation of learning takes place the teacher conducts assessment to know the achievement of learners towards the understanding of the concepts and skills undertaken. Learners who have not understood concepts and skills will be described further. In general, the difficulty of learners lies in the union of objects in a flat mirror and in a convex mirror.

Optical learning at the third meeting discusses and practices shadow formation in convex lenses. The first stage of observation, the teacher asks the question "How the process of shaping objects from convex lens? Does the distance of the object affect the distance of the shadow? "Next the learner conducts the experiment based on the activity sheet and observes by observing the distance of the object and the distance of the shadow to the lens. The second stage of manipulation, the teacher asks the question "What is the focal length of the convex lens?" Next learners manipulate the independent variables with the distance of different objects and get the distance of different shadows also against the lens. The third stage of generalization, the teacher had calculated the focus distance of the convex lens. Further learners do calculations to find the focus distance based on the distance data objects and the distance of the shadow that collected. The fourth stage of verification, the teacher asked to make a conclusion. Further learners make conclusions and match the results of calculations with the focus distance of the actual convex lens. The fifth stage of application, the teacher gives a number of problems to apply the calculation based on the data made. Further learners calculate the distance and shadow properties based on the data provided. When the implementation of learning takes place the teacher conducts assessment to know the achievement of learners towards the understanding of the concepts and skills undertaken. Learners who have not understood concepts and skills will be teached further. In general, learners do not experience difficulties when learning takes place.

Optical learning at the fourth meeting discusses and practices the formation of shadows on concave lenses. The first stage of observation, the teacher asks the question "How the process of shadow forming objects from the concave lens? Does the distance of the object affect the distance of the shadow?" Next, the students experiment based on the activity sheet and observe by observing the distance of the object and the distance of the shadow against the concave lens. At this stage determine the distance of object shadow using the help of convex lens. The second stage of manipulation, the teacher asks the question "What is the focal distance of the concave lens?" Then, the learners manipulate the independent variables with the distance of different objects and get the distance of different shadows also against the concave lens. The third stage of generalization, the teacher had to calculate the focus distance of the concave lens. Further, learners do calculations to find the focus distance based on the distance data objects and the distance of the shadow that collected. The fourth stage of verification, the teacher asked to make a conclusion. Furthermore, learners make conclusions and match the results of calculations with the focus distance of the actual concave lens. The fifth stage of application, the teacher gives a number of problems to apply the calculation based on the data made. Further learners calculate the distance and shadow properties based on the data provided. When the implementation of learning takes place the teacher conducts assessment to know the achievement of learners towards the understanding of the concepts and skills undertaken. Learners who have not understood concepts and skills will be described further. In general, learners initially have difficulty when determining the shadow after putting a concave lens between convex lenses with shadows. This happens because the object used is virtual which comes from the shadow objects from the convex lens.

After the learning optics through the inquiry laboratory approach, then performed the final test to see the differences and improvement of learning outcomes. From the final test results obtained a minimum score of 30 and increased by 21 , the maximum score of 78 and increased by 30 , the average score 51 and increased by 26 . The increase in the average Ngain obtained by 0.35 . the instruments used show homogenity and normality based on the Kurtosis normality test. The results of the initial and final test also showed differences based on the $\mathrm{Sig}$ ( 2 tailed) $\mathrm{t}$ test with a significance of 0.000 .

\section{CONCLUSION}

The diagnostic assessment in learning optics based on inquiry laboratory demonstrates the difference and improvement of optical learning outcomes for understanding the concept of mirror and lens materials. The results show that the implementation of the diagnostic assessment of the learners is very well done. It is very helpful for teachers to know the initial capability and the necessary needs in the learning that will be implemented.

\section{REFERENCES}

[1] Kemdikbud. 2017. Buku Guru Ilmu Pengetahuan Alam VIII. Kemdikbud. Jakarta.

[2] R.I. Arends. 2012. Learning to Teach. 9th Ed. McGraw Hill Companies. Inc. New York.

[3] Permendikbud Nomor 23 Tahun 2016 Tentang Standar Penilaian Pendidikan.

[4] R. Qadar. 2015. Pengembangan Asesmen Terintegrasi Pembelajaran Inkuiri pada Perkuliahan Optika Calon Guru Fisika. Disertasi. SPs UPI Bandung: Tidak dipublikasikan.

[5] L.W. Anderson and D.R. Krathwohl. (2001). A Taxonomy for Learning, Teaching, and Assessing:A Revision of Bloom's Taxonomy of Educational Objectives. Longman. New York.

[6] L.A. Tomei. 2005. Taxonomy for the Technology Domain. Information Science Publishing. Hershey.

[7] R. Qadar, N.Y. Rustaman, dan A. Suhandi. 2015. Mengakses Aspek Afektif dan Kognitif pada Pembelajaran Optika dengan Pendekatan Demonstrasi Interaktif. Jurnal Inovasi dan Pembelajaran Fisika.Pend. Fisika FKIP Unsri Palembang. 2(1), 1 - 11. 
[8] R. Qadar, N.Y. Rustaman, dan A. Suhandi. 2014. Asesmen Kemampuan Berinkuiri pada Pembelajaran Lensa Tipis dengan Pendekatan Laboratorium Inkuiri. Prosiding Seminar Nasional Pendidikan IPA 2014. FMIPA Unesa Surabaya. 608-614.

[9] R. Qadar, N.Y. Rustaman, dan A. Suhandi. 2015. Mengakses Kemampuan Berinkuiri Calon Guru Fisika Melalui Pendekatan Inkuiri Level Demonstrasi Interaktif. Jurnal Riset Pendidikan Fisika. Jurusan Pendidikan Fisika UNM Malang. 33-40.

[10] R. Doran, F. Chan, and C. Lenhardt. 2002. Science Educator's Guide to Laboratory Assessment. NSTA Press. Virginia.
[11] Wenning, C.J. 2005. Levels of Inquiry: Hierarchies of Pedagogical Practices and Inquiry Processes. Journal of Physics Teacher Education Online. 2(3).3-11. wenning@phy.ilstu.edu (online:10 September 2017).

[12] Wenning, C.J. 2010. The Levels of Inquiry: Using Inquiry Spectrum Learning Sequences to Teach Science. Journal of Physics Teacher Education Online. 5(4). 11-20. Summer. wenning@phy.ilstu.edu (online: 10 September 2017).

[13] Wenning, C.J. 2011. The Levels of Inquiry Model of Science Teaching. Journal of Physics Teacher Education Online. 6(2). 9-16. Summer.wenning@phy.ilstu.edu (online: 10 September 2017). 